\title{
Teknik Reframing untuk mengurangi pemikiran negatif pada wanita depresi dengan gejala psikotik
}

\author{
Niken Refanthira ${ }^{1}$
}

\begin{abstract}
Individuals who experience depression generally have negative thoughts. The purpose of this study was to see the effectiveness of reframing to reduce negative thoughts in depression sufferers with psychotic symptoms. This research uses a qualitative case study approach with one subject. The instruments used were interviews, observations, Beck Depression Inventory scale, World Health Organization: Disability Assessment Schedule scale, and Standard Progressive Matrixes test. The treatment given to the subject is cognitive therapy with reframing techniques by changing the way the subject perceives the problem. The intervention was carried out with several stages with results showing that reframing was able to refram wrong thinking and could be applied to individuals who had below average intelligence through family assistance and a high desire to recover.
\end{abstract}

\section{Keywords}

Depression with psychotic symptoms, negative thinking, reframing, women

\section{Pendahuluan}

Depresi adalah salah satu gangguan jiwa yang membuat penderitanya merasakan perubahan suasana hati, pikiran, perilaku, dan kesehatan fisik (Fekadu et al., 2017). Depresi mengacu pada berbagai masalah kesehatan mental yang ditandai dengan tidak adanya pengaruh positif (Astuti et al., 2010). Depresi menjadi gangguan yang merusak atau menurunkan kualitas hidup (Chin et al., 2014; Cuijpers et al., 2020). Penderita depresi tidak memiliki motivasi untuk hidup dan cenderung berpikir untuk mengakhiri hidupnya. Depresi atau yang sering disebut Major Depressive Disorder yang dibagi atas tiga tingkat yaitu depresi ringan, depresi sedang, dan depresi berat. Memiliki dua bentuk episode yaitu episode tunggal dan episode berulang. Penderita depresi juga memungkinkan mengalami gejala psikotik seperti halusinasi dan delusi (American Psychiatric Association, 2013). Penelitian sebelumnya menyatakan bahwa depresi dapat diobati dengan efektif melalui terapi kognitif sesuai dengan tingkat keparahan depresi yang dimiliki (Iddon \& Grant, 2013). Pada abad ini, kognitif telah dikembangkan menjadi lebih modern seperti menggunakan internet dalam terapinya, meski terapi tersebut masih kurang valid karena sedikit banyak faktor yang mempengaruhi sehingga masih membutuhkan penelitian tambahan (Berg et al., 2020).

Menurut penelitian sebelumnya, gejala depresi dapat terjadi pada individu yang memiliki masalah sosial, masalah keluarga, dan masalah dalam hubungan sebagai faktor eksternal (Leung et al., 2012). Gejala depresi juga dapat memiliki faktor dari masalah lintas budaya (Ghorbani et al., 2008) dan orientasi agama dari individu (Amrai et al., 2011). Depresi merugikan individu secara psikososial, emosional, melemahkan fungsi interpersonal, dan kinerja akademis. Penderita depresi ditandai dengan gejala penurunan suasana hati, tidak ingin melakukan aktifitas apapun, adanya penurunan berat badan meski tidak diet, insomnia, penurunan kognitif, cepat lelah, perasaan bersalah yang berlebihan, sulit konsentrasi, dan keinginan untuk mengakhiri hidup (American Psychiatric Association, 2013). Semakin besar keparahan depresi, maka semakin besar pula morbiditas dan konsekuensi yang dapat merugikan penderitanya (National Institute for Health \& Clinical Excellence, 2010). Banyak dari pasien depresi diobati melalui obat-obatan maupun terapi psikologis (Chin et al., 2014).

Penderita depresi berhubungan dengan pemikiran negatif yang dimiliki tentang diri maupun orang lain. Penelitian sebelumnya menyatakan bahwa penderita depresi berpandangan negatif yang membatasi pemikiran luas sehingga menjadi masalah untuk dirinya sendiri hingga memperlihatkan perilaku yang menonjol, perilaku-perilaku tersebut dapat berupa gejala depresi yang dimiliki penderita (Pietromonaco \& Markus, 1985). Penelitian sebelumnya menyatakan bahwa efek dari fungsi keluarga, harga diri, dan pemikiran negatif mempengaruhi depresi (Nasir et al., 2010).

Pemikiran negatif menciptakan kecemasan dan menjadi target penting dalam penanganan klinis. Meskipun terdapat pengaruh positif seperti penelitian sebelumnya yang menyatakan bahwa pemikiran negatif dapat menjadi pengaruh positif jika dikaitkan dengan harga diri dan optimisme. Pemikiran negatif dapat membantu penderita depresi dapat memulihkan diri sebelum pindah ke daerah baru dan penderita kecemasan juga lebih berhati-hati dalam berperilaku

${ }^{1}$ Universitas Muhammadiyah Malang, Indonesia

\section{Korespondensi:}

Niken Refanthira, Direktorat Program Pascasarjana, Universitas Muhammadiyah Malang, Jl. Tlogomas 246 Malang, Indonesia

Email: rfnthr04@gmail.com 
sehingga menghindari kemungkinan yang berbahaya (Sasaki et al., 2013). Dalam penelitian sebelumnya, memperlihatkan adanya hubungan teori kognitif dengan pemikiran negatif yang memperlihatkan pemikiran negatif lebih banyak untuk diri sendiri dan masa depan (Mohammadkhani et al., 2018).

Ada berbagai bentuk depresi dari kondisi ringan hingga sangat parah seperti depresi dengan gejala psikotik yang menunjukkan adanya halusinasi dan delusi pada penderitanya (Fekadu et al., 2017). Depresi dengan gejala psikotik adalah salah satu kelainan mental yang cukup parah namun kurang terdiagnosis dan seringnya tidak menjadi fokus dalam penanganan. Depresi dengan geja apsikotik tidak menjadi sesuatu yang menarik bagi dokter, peneliti, dan industri farmasi untuk diteliti sehingga praktik klinis tentang kelainan mental ini masih sangat jarang untuk ditangani (Leadholm et al., 2013).

Penelitian sebelumnya menyatakan bahwa psikotik sangat umum terjadi diantara pasien tua yang menderita psikotik. Penelitian sebelumnya menyatakan bahwa psikotik dapat terjadi pada usia lanjut daripada usia dewasa (Ozdemir et al., 2015). Depresi psikotik mendapatkan obat-obatan berupa antipsikotik dan antidepresan. Kombinasi keduanya efektif untuk digunakan sebagai monoterapi (Rothschild, 2013). Penelitian menunjukkan bahwa depresi lebih sering terjadi pada wanita dibanding laki-laki sebanyak dua kali lipat karena berhubungan dengan perbedaan sosialisasi antara laki-laki dan perempuan yang mudah menghasilkan emosi, kognisi, dan reaksi koping yang berbeda (Al Omari et al., 2020).

Pada penelitian sebelumnya depresi dengan gejala psikotik menjadi penyakit psikosis yang dapat menjadi perhatian banyak orang. Banyak penderita depresi dengan gejala psikotik mencoba untuk mengakhiri hidupnya. Durasi kekambuhan lebih panjang dan tingkat kekambuhan lebih tinggi daripada depresi tanpa gejala psikotik (Tyrka et al., 2006). Depresi juga mempengaruhi gaya hidup dan kemampuan untuk melakukan kegiatan sehari-hari. Orang dengan diabetes juga memiliki kemungkinan untuk mengalami depresi sehingga penyakit mental ini menjadi masalah yang cukup mengganggu bagi masyarakat (Tusa et al., 2020).

Depresi dan kecemasan semakin memburuk semenjak pandemi berlangsung. Perubahan kegiatan dan gaya hidup memberikan dampak negatif bagi masyarakat terhadap kesehatan mental mereka (Choi et al., 2020). Pada masa pandemi seperti saat ini depresi mudah muncul karena ketakutan masyarakat terhadap pandemi. Penelitian lain menyatakan bahwa coping yang positif dapat menjadi manajemen stres yang baik selama masa pandemi berlangsung (Skapinakis et al., 2020). Menerapkan sosialisasi dan bantuan psikologis terkait bagaimana upaya meningkatkan coping yang positif selama masa pandemi dapat meningkatkan kesehatan mental masyarakat sehingga terhindari dari stres dan depresi (Al Omari et al., 2020).

Terapi yang akan digunakan dalam penelitian ini adalah terapi kognitif dengan teknik reframing. Reframing adalah salah satu teknik dari terapi kognitif terhadap subjek untuk menurunkan pemikiran negatif serta mengubah bagaimana subjek memandang masalah sehingga subjek mampu mengembangkan cara pandang baru terhadap masalah yang dimilikinya. Reframing merupakan teknik teurapeutik yang digunakan untuk mengubah persepsi diri terhadap keyakinan negatif, terdistorsi, atau merugikan diri sendiri dengan tujuan mengubah perilaku atau meningkatkan kesejahteraan (Robson Jr \& Troutman-Jordan, 2014).

Tujuan dalam studi ini untuk melihat efektifitas teknik reframing terhadap penderita depresi dengan gejala psikotik. Target menurunkan gejala depresi dan memberikan pandangan-pandangan baru terhadap pemikiran yang salah dari subjek. Manfaat dalam penelitian ini yaitu memberikan perkembangan baru terhadap intervensi khususnya teknik reframing dalam menurunkan pemikiran negatif pada penderita depresi dengan gejala psikotik, dan juga menjadi referensi baru untuk peneliti dimasa depan terhadap perkembangan teknik reframing bagi penderita depresi dengan gejala psikotik.

\section{Tinjauan Pustaka dan Hipotesis}

\section{Kerangka Teori}

Depresi merupakan sebuah gangguan jiwa yang memiliki simptom perubahan suasana hati, perilaku, dan pikiran. Ditandai dengan adanya keinginan untuk melakukan bunuh diri, kehilangan minat untuk beraktifitas, merasa tidak bahagia, dan munculnya pemikiran negatif terhadap diri dan orang lain. Depresi memiliki dua bentuk episode, yaitu episode tunggal dan episode berulang dengan berbagai jenis depresi seperti distruptive mood dysregulation, gangguan depresi berat, gangguan depresi persisten, premenstual dysphoric disorder, substance/medication-induce depressive disorder, gangguan depresi yang berhubungan dengan kondisi medis lainnya, gangguan depresi yang tidak spesifik, dan gangguan depresi yang tidak tergolongkan (American Psychiatric Association, 2013).

Pemikiran negatif dimiliki oleh penderita depresi yang diikuti dengan penurunan suasana hati, keinginan untuk bunuh diri, kurangnya minat beraktifitas, adanya perasaan bersalah, mudah lelah, adanya penurunan kognitif, dan sulit berkonsentrasi (Sasaki et al., 2013). Ciri utama dari depresi berat ditandai dengan pemikiran negatif yang meningkat terhadap diri individu (Philippi et al., 2018). Pemikiran negatif berasal dari pemikiran yang salah dari individu yang sulit untuk memilah pemikiran dan akhirnya mempersepsikan diri dan orang lain secara salah (Pietromonaco \& Markus, 1985).

Pemikiran negatif yang dimiliki individu yang menderita depresi dapat mempengaruhi berbagai macam kegiatan sehingga menjadikan masalah dalam kehidupan individu (Sasaki et al., 2013). Pemikiran negatif yang muncul membuat individu meyakini pemikiran yang salah menjadi pemikiran yang benar sehingga individu menyalahkan dirinya dan depresi (Power \& Dalgeish, 2008). Pemikiran negatif cenderung berulang dan menjadi tidak terkendali sehingga menjadi kerentanan bagi depresi untuk kambuh (Figueroa et al., 2015). Depresi memiliki tiga pandangan negatif terhadap masa lalunya, yaitu pandangan negatif terhadap dirinya sendiri, pada pengalaman masa lalunya, dan masa depannya (Nelson-Jones, 2006). Ketika seseorang memiliki gejala depresi, individu akan berpikir untuk mengakhiri hidupnya dikarenakan depresi, pemikiran negatif, dan perilaku bunuh diri saling berkaitan (Choon et al., 2014). 
Reframing merupakan sebuah teknik terapi yang didasari melalui pendekatan kognitif dan berpusat pada kognitif individu yang membantu individu mengatur ulang pemikiran sehingga mampu menyelesaikan dan melihat masalah dari sudut pandang yang berbeda (Erford, 2017). Reframing membantu individu untuk berpikir lebih positif dan produktif sehingga memberikan pandangan bahwa kejadian atau peristiwa yang terjadi dapat dilihat dari segi pandang yang lain (Robson Jr \& Troutman-Jordan, 2014). Pembingkaian ulang memberikan individu perubahan pola pikir dari negatif ke arah positif dan memberikan bantuan pada masalah individu untuk menempatkan diri dalam situasi atau keadaan dengan bingkai pandangan yang berbeda sehingga individu memiliki fakta lain dan mampu meninjau masalahnya secara lebih luas sehingga reframing menjadi salah satu teknik yang dapat menangani masalah depresi (Leung et al., 2012). Teknik ini dapat menjadi alternatif pengobatan bagi penderita depresi (Iddon \& Grant, 2013). Pendekatan kognitif juga berkembang sesuai dengan perkembangan modernisasi yang dapat menciptakan lebih banyak alternatif dalam pendekatan kognitif (Berg et al., 2020). Melalui teknik ini, individu dengan depresi yang memiliki pemikiran negatif pada dirinya maupun orang lain dapat mengubah pola pikir dan memberikan pandangan yang baru terhadap masalah.

\section{Hipotesis}

Reframing efektif untuk menurunkan pemikiran negatif pada penderita depresi dengan gejala psikotik

\section{Metode Penelitian}

\section{Desain Penelitian}

Penelitian ini menggunakan pendekatan studi kasus single subject dengan jenis kualitatif. Studi kasus atau case study adalah sebuah model penelitian yang mengarah pada eksplorasi pada sebuah kasus khusus dan digali secara lebih detail (Creswell, 2015). Studi kasus memiliki ciri-ciri kualitatif dan mengarah pada sebuah peristiwa atau kondisi tertentu (Prihatsanti et al., 2018). Desain subjek tunggal adalah sebuah metode yang mengacu pada fakta dimana subjek adalah kontrolnya sendiri dan data yang dikumpulkan dapat dianalisis pada fase intervensi dan dibandingkan dengan fase sebelum intervensi dilakukan (Alnahdi, 2015). Subjek

Nana (nama samaran) berumur 27 tahun, adalah seorang wanita yang tinggal di Malang dengan tingkat pendidikan strata satu, berstatus menikah, ibu rumah tangga, dan memiliki dua anak. Subjek mengalami depresi dengan gejala psikotik. Sebelumnya, subjek belum pernah datang ke psikolog dan hanya mendapatkan obat untuk membantunya tidur dari psikiater tanpa diperiksa lebih lanjut terkait masalah-masalah yang dihadapinya. Subjek dipilih berdasarkan kriteria yang sesuai dan keunikan pada permasalahan yang sesuai dengan fenomena yang didapatkan.

\section{Instrumen dan Prosedur asesmen}

Instrumen yang digunakan adalah sebagai berikut.

1. Wawancara, untuk mengetahui keluhan dan riwayat keluhan subjek terhadap pemikiran negatif juga gejalagejala depresi yang muncul. Pertanyaan-pertanyaan yang diberikan adalah wawancara semi-terstruktur dan tergantung kebutuhan terapis. Wawancara digunakan saat sebelum intervensi untuk menemukan riwayat keluhan, digunakan selama proses intervensi berlangsung untuk melihat proses peningkatan dan pemahaman intervensi, dan asesmen setelah intervensi dilaksanakan digunakan untuk melihat bagaimana subjek memahami intervensi yang telah diberikan

2. Observasi, untuk melihat perilaku saat asesmen dan intervensi berlangsung. Melihat peningkatan subjek dalam pola pikir sebelum intervensi, selama intervensi, dan setelah intervensi.

3. Skala Beck Depression Inventory (BDI), untuk melihat berada pada kategori apa depresi dan sebagai sebelum dan sesudah untuk penentu keberhasilan intervensi. Aspek yang dilihat dalam BDI adalah perasaan, rasa percaya diri, rasa bersalah, dan perubahan kegiatan fisik. Reliabilitas dari BDI yang dikembangkan oleh Beck memiliki reliabilitas konsistensi yang tinggi yaitu 0,9 (Sorayah, 2015). Skala ini digunakan saat sebelum intervensi untuk melihat kondisi awal dan setelah intervensi untuk melihat efek dari intervensi yang telah diberikan sebagai alat ukur follow up.

4. Skala World Health Organization: Disability Assessment Schedule (WHODAS), untuk melihat keberfungsian subjek terhadap kegiatan sehari-hari agar dapat melihat apakah subjek terganggu dalam keseharian atau tidak. Reliabilitas pada WHODAS yang dikembangkan oleh WHO (World Health Organization) ini memiliki koefisien intra-class 0,69 hingga 0,89, 0,93 hingga 0,96 pada tingkat domain, dan keseluruhannya 0,98 (Üstün et al., 2010). Aspek yang didapatkan melalui WHODAS adalah komunikasi, aktifitas gerak, perawatan diri, hubungan sosial, kegiatan diluar rumah yang mencakup lingkungan kerja, sekolah, dan masyarakat. Skala ini digunakan sebelum intervensi untuk melihat keberfungsian subjek selama 30 hari terakhir.

5. Tes Standard Progressive Matrixes (SPM), untuk mengukur intelegensi subjek agar dapat melihat kemampuan subjek dalam menerima treatment yang akan diberikan dan membantu terapis dalam penyampaian kata-kata sehingga dimengerti dengan mudah oleh subjek. Tes ini dikembangkan oleh Raven dengan reliabilitas jangka pendek 0,90 yang dikurangi menjadi 0,80 dengan jangka lama (Vass, 1992). Tes ini digunakan saat asesmen sebelum intervensi dilakukan.

Prosedur yang digunakan ada tiga tahap yaitu asesmen awal, asesmen yang dilakukan selama proses intervensi, serta asesmen yang dilakukan setelah intervensi.

\section{Analisis Data}

Analisis data yang digunakan adalah analisis kualitatif dengan yaitu analisis tematik yaitu sebuah metode analisis yang mampu mendeskripsikan data dengan mengidentifikasi pola sehingga menemukan tema dari data yang dimiliki. Metode analisis ini digunakan pada ilmu sosial dan memperlihatkan bagaimana data di implementasikan dalam menganalisa sebuah penelitian (Heriyanto, 2018). 


\section{Analisis Kasus}

\section{Presentasi Kasus}

Nana (nama samaran) berumur 27 tahun dan menyatakan bahwa dirinya mengalami perasaan yang tidak nyaman selama setahun terakhir. Diawali dengan rasa bersalah karena kematian anak dalam kandungannya, membuat Nana membawa rasa bersalah tersebut hingga saat ini. Nana menyatakan bahwa dirinya merasa tidak bahagia, suami tidak mencintai dirinya dan hanya berusaha mempertahankan rumah tangga demi anak-anak mereka.

Orang-orang disekitarnya selalu menghakiminya dengan berbagai pendapat negatif seperti menyatakan dirinya tidak begitu cantik atau pendapat seperti percuma sarjana jika tidak bekerja. Namun ketika mereka memuji, Nana tidak percaya bahwa pujian itu benar untuk dirinya. Nana mengembangkan pikiran negatif terhadap dirinya seperti Nana merasa bahwa ia tidak berguna, Nana merasa semua yang terjadi adalah kesalahannya. Nana memiliki pengalaman yang tidak menyenangkan sejak kecil sehingga semua itu menjadi penguatan bagi Nana. Nana tidak menyadari bahwa selama ini pemikirannya adalah pemikiran negatif, namun Nana merasa bahwa setiap masalah menjadi besar karena caranya berpikir.

Pemikiran-pemikiran negatif berawal sejak Nana menikah. Nana berpikir bahwa ibunya tidak mencintainya karena selalu memaksanya untuk bekerja. Nana akhirnya hamil anak pertama namun harus digugurkan karena Nana menderita virus tokso, saat itu Nana berpikir bahwa kematian janinnya adalah kesalahannya. Kejadian tersebut akhirnya membuat Nana mengalami halusinasi pendengaran dan penglihatan.

Ketika Nana melahirkan anak pertama dan anak kedua, Nana berpikir bahwa suami hanya mencintai Nana karena anak-anak. Ketika anak-anak Nana mulai tumbuh dan selalu memilih ayah daripada bunda, Nana merasa anak-anak tidak membutuhkan Nana. Dalam ruang lingkup pertemanan, Nana banyak dihakimi atas apa yang Nana lakukan. Ucapan-ucapan tersebut membuat Nana mengembangkan pemikiran negatif. Nana berpikir bahwa pujian yang ia terima adalah kebohongan yang orang lain ungkapkan, sedangkan ucapan negatif bagi orang lain Nana terima yang membuat pikirannya menjadi terbebani. Proses tersebut berlangsung sampai saat ini. Nana menderita depresi berat karena banyaknya pemikiran-pemikiran negatif.

Penderita depresi berhubungan dengan pemikiran negatif yang dimiliki tentang diri maupun orang lain (Pietromonaco \& Markus, 1985). Penderita depresi mengalami pandangan negatif tentang dirinya, sama seperti yang Nana alami. Individu yang berpandangan negatif pada diri membuat individu memiliki sikap yang negatif dan akhirnya berefek pada banyak hal dalam hidupnya (Permuy et al., 2010).

Nana menolak untuk percaya ketika seseorang memujinya, namun merasa yakin ketika seseorang berkomentar buruk tentangnya dan menyikapi bahwa dirinya memang tidak pantas, tidak berguna, penuh kesalahan, dan tidak dicintai oleh orang lain. Pemikiran negatif mempengaruhi depresi dan menjadikannya masalah dalam kehidupannya (Sasaki et al., 2013). Melalui kasus ini memperlihatkan pemikiran-pemikiran negatif sehingga target yang akan menjadi fokus intervensi adalah mengubah pemikiran negatif dan menurunkan gejala depresi dari subjek.

Nana di diagnosa depresi berat dengan gejala psikotik. Nana mengalami gejala depresi yang hampir setiap hari selama 8 tahun terakhir. Gejala depresi berupa kehilangan minat untuk beraktifitas sehingga fungsi keseharian terganggu karena Nana hanya suka berdiam diri dikamar, insomnia hingga mengonsumsi obat tidur, merasa bersalah hampir setiap hari tentang kehidupan saat ini dan masa lalu, melakukan percobaan bunuh diri beberapa kali namun gagal. Selain itu, Nana mendengar seseorang yang mengatakan bahwa ia tak pantas hidup dan tidak berguna bagi anak-anaknya dan halusinasi penglihatan seorang anak lakilaki yang terus mengikutinya juga bapak-bapak yang selalu berada dirumahnya.

Depresi ditandai dengan ketidakberfungsian proses berpikir yang ditandai dengan sikap pesimis, sikap negatif yang berlebihan dalam menilai diri, berasumsi yang berlebihan tentang kesulitan atau masalah diri hingga dunia sehingga kesulitan untuk menemukan jalan keluar dari masalah sehingga munculnya pikiran otomatis yang negatif yang berasal dari keyakinan dan asumsi (Sturmey, 2009). Adanya gejala penurunan suasana hati, tidak ingin melakukan aktifitas apapun, adanya penurunan berat badan meski tidak diet, insomnia, adanya penurunan kognitif, cepat lelah, perasaan bersalah yang berlebihan, sulit konsentrasi, keinginan untuk mengakhiri hidup yang tinggi (American Psychiatric Association, 2013). Gaya berpikir penderita depresi cenderung kaku dan mandiri sehingga menghambat penderita untuk merancang solusi baru untuk masalah mereka. Gaya berpikir terbentuk selama pengalaman awal yaitu pengalaman masa kecil khususnya yang terjadi dalam ruang lingkup keluarga sehingga membentuk pemahaman insidivu tentang dunia dan menjadi pengaruh bagi perencanaan individu dimasa depan (Beck, 1967, Rush).

Depresi atau yang sering disebut Major Depressive Disorder yang dibagi atas tiga tingkat yaitu depresi ringan, depresi sedang, dan depresi berat. Depresi mempunyai dua bentuk episode yaitu episode tunggal dan episode berulang. Penderita depresi juga mengalami gejala psikotik seperti halusinasi dan delusi (American Psychiatric Association, 2013). Model kognitif depresi menekankan efek dari jenis kognisi negatif tertentu dalam etiologi depresi. Model kognitif depresi mengusulkan bahwa kognisi negatif menghasilkan gejala depresi. Model kognitif menunjukkan kognisi negatif tertentu yang memiliki peran dalam permulaan dan pemeliharaan depresi (Teasdale, 1983).

Pengalaman Awal setelah Kematian Ayah. Pada perjalanan kehidupannya Nana mengalami banyak masa lalu yang berat untuk dijalani. Pengalaman dimasa kecilnya dimulai dengan ayahnya yang meninggal saat usianya empat tahun, membuatnya harus hidup berdua dengan ibu karena Nana adalah anak tunggal. Ibu Nana akhirnya mulai mencari pekerjaan untuk membiayai sekolah Nana. Menurut Nana, ibu Nana adalah orang yang begitu tertarik dengan uang sehingga ibu Nana sering meminjami uang dan tidak mampu menabung sehingga hutang keluarganya bertumpuk. 
Saat ibu Nana harus bekerja, Nana dititipkan dirumah tetangganya dengan teman seumuran sehingga Nana sering bermain ke rumah tersebut. Namun hal yang tidak ia inginkan terjadi, Nana dilecehkan secara seksual oleh seorang laki-laki dirumah tempat ia dititipkan oleh ibunya. Namun Nana tidak berani mengatakan hal tersebut pada ibunya karena laki-laki tersebut mengancam jika ia mengatakan ke ibunya maka Nana tidak boleh lagi main dirumah tetangga tersebut. Pengalaman tersebut Nana simpan sampai ia besar dan tidak satupun yang mengetahui pelecehan yang ia miliki. Nana merasa malu dengan pengalaman masa kecil tersebut dan takut untuk bertemu dengan laki-laki yang pernah melecehkannya.

Mendapatkan Pelecehan. Pada masa remaja saat Nana berusia 17 tahun, Nana dan ibunya mengalami masalah ekonomi yang membuat Nana harus bekerja sambil sekolah untuk membantu ibunya membiayai sekolahnya. Nana merasa bahwa belajar sambil bekerja sangat berat untuk ia jalani, namun keinginannya untuk sekolah membuatnya harus melanjutkan kegiatan tersebut. Disisi lain, ibunya tidak membantu Nana dan lebih memilih menghabiskan uang untuk keperluan pribadi yang tidak penting sehingga Nana merasa kesulitan karena ibunya bahkan meminta uang padanya sesekali, ibunya tak berhenti membuat hutang pada orang lain. Meskipun begitu Nana lulus di SMA dan seorang laki-laki tertarik padanya sehingga berpikir untuk serius dengannya.

Dikarenakan pengalaman di masa lalu, Nana tidak terlalu menerima lelaki tersebut. Namun Nana mengenalkan lelaki tersebut pada ibunya, dan ibunya menyetujui keseriusan lelaki tersebut. Lelaki itu juga membayar semua hutang ibu Nana dan membantu Nana untuk sekolah. Nana akhirnya menikah dengan lelaki yang disetujui ibunya. Nana menyatakan bahwa ia tidak menyukai lelaki yang menjadi suaminya, ia hanya mengikuti apa yang ibunya inginkan karena lelaki tersebut baik dan telah melunasi hutang keluarganya. Karena suaminya subjek disekolahkan hingga sarjana disebuah universitas di Malang.

Munculnya Depresi dan Halusinasi. Pada umur 20 tahun setelah beberapa tahun pernikahan Nana akhirnya mengandung anak pertama. Namun dalam usia kandungan empat bulan Nana harus kehilangan janinnya karena virus tokso yang ia miliki membuat kandungan Nana tidak berkembang sebagaimana mestinya. Hal tersebut membuat Nana merasa sedih karena kehilangan anak pertamanya dan merasa bahwa semua hal ini adalah kesalahannya, Nana marah pada dirinya sendiri dan membenci dirinya sendiri karena masalah tersebut meski suaminya telah mengatakan bahwa itu bukan kesalahannya.

Nana akhirnya mengandung lagi tak lama kemudian dan Nana cukup menyayangi kandungannya. Nana juga melakukan pemeriksaan terhadap virus tokso dan hasilnya negatif. Namun pada umur 25 tahun ketika Nana mulai membesarkan anaknya Nana merasa tidak berguna karena Nana tidak bisa membesarkan anak-anaknya. Nana merasa tidak pantas menjadi seorang ibu untuk anaknya. Pada saat itu Nana mulai berpikir ingin mengakhiri hidupnya karena merasa gagal menjadi seorang ibu.

Pada umur 27 tahun, Nana mulai dibayangi oleh halusinasi anak pertamanya yang ia beri nama Chan (nama samaran). Nana meyakini bahwa anak laki-laki yang ia lihat adalah sosok anak pertamanya yang sudah meninggal. Keyakinan Nana membuatnya berinteraksi dengan halusinasi yang ia pikir adalah anaknya. Selain itu Nana juga mendapatkan halusinasi pendengaran yang ia yakini adalah suara anaknya. Anaknya membisikkan hal-hal negatif seperti memintanya untuk mati, mengatakan bahwa dirinya tidak pantas menjadi seorang ibu, menyalahkannya atas kematian anak pertamanya membuat Nana merasa terganggu dengan semua bisikan-bisikan meskipun ia tau bahwa ucapan itu memang kesalahannya dan ia merasa tidak pantas menjadi seorang ibu. Penglihatan dan pendengaran tersebut masih ada hingga Nana bertemu dengan psikolog. Nana juga mulai terbebani oleh pikiran dari komentar-komentar buruk yang orang-orang berikan kepadanya tentang hidupnya, terlalu mempedulikan ucapan orang lain, dan tidak percaya ketika ia di puji orang lain karena ia merasa itu hanya kebohongan.

\section{Analisis}

Dalam partisipasi masyarakat Nana memilih untuk menghindari situasi yang ramai karena Nana tidak nyaman berada disekitar orang asing. Nana cenderung menarik diri dari sosial, tidak tertarik untuk berhubungan hangat dengan orang lain, bersikap impulsif, cenderung memberontak, konflik dengan keluarga, dan hubungan interpersonal yang buruk. Dalam pengukuran yang diberikan sebelum intervensi memperlihatkan bahwa Nana berada pada tahap depresi berat. Terlihat melalui observasi bahwa Nana sering menangis, merasa tidak bahagia, merasa depresi sepanjang hari.

Hasil dari intelegensi Nana adalah golongan borderline atau dapat dikatakan dengan kategori dibawah rata-rata, namun dalam observasi Nana mampu menjawab pertanyaan dengan tenang dan tidak kebingungan, mampu memilih kata yang baik dalam menyusun sebuah kalimat, dan tidak memperlihatkan kesulitan dalam memahami pertanyaan yang diajukan. Latar belakang pendidikan Nana adalah strata satu meskipun Nana memperlihatkan gejala retardasi namun hal ini menjadi salah satu gejala depresi berat dengan kriteria penurunan fungsi kognitif. Nana menyatakan bahwa pikiran negatif muncul secara otomatis dimana pikiran otomatis sulit untuk diakses oleh kesadaran.

Ketika masalah terjadi, pikiran negatif muncul saat individu cenderung menyalahkan diri sehingga akhirnya merasa depresi (Power \& Dalgeish, 2008). Depresi bukan hanya berasal dari gangguan emosi namun juga bagian dari mekanisme interaksi yang meliputi biologis, psikologis, dan faktor sosial (Power \& Dalgeish, 2008). Distorsi kognitif adalah dasar negatif dalam pemikiran yang mewakili faktor kerentanan untuk depresi. Distorsi kognitif dikaitkan dengan kendala penekanan yang ditempatkan dalam konteks teori dan praktik kognitif. Distorsi adalah gejala yang dikenali dan tampak menonjol dalam teori dan terapi kognitif,distorsi dapat dikenali dan berdampak pada gangguan psikologis yang melibatkan pikiran tentang diri sendiri danorang lain secara negatif (Rnic et al., 2016).

Peristiwa yang berkembang dan mengarah pada pembentukan sikap disfungsional yang berhubungan dengan pengalaman buruk sehingga mengarah ke depresi. Melalui penelitian sebelumnya menyatakan bahwa pasien dengan depresi berat yang mengalami kehilangan orang tua dimasa anak-anak membuat anak lebih rentan memicu depresi 
dimasa depan (Beck, 2008). Ketika seseorang dengan kecenderungan depresi kehilangan seseorang dimasa lalunya kemudian kehilangan seseorang dimasa dewasanya akan lebih membuat penderita peka terhadap peristiwa negatif yang dimiliki sehingga dapat menyebabkan depresi lebih mudah (Beck, 2008).

Beck (2008) telah diformasi teorinya untuk gangguan depresi. Menurutnya pola pikir individu itu adalah sumber masalah utama, khususnya cara pandang negatif terhadap diri sendiri, orang lain, dan lingkungannya. Adanya kesalahan dalam memproses informasi sehingga kesimpulan yang didapatkan juga salah. Kognisi adalah kunci untuk memahami dan menangani gangguan psikologis (NelsonJones, 2006). Kognisi adalah proses yang melibatkan berbagai hubungan yang kompleks diantara berbagai kejadian sebagai tujuan untuk adaptasi (Nelson-Jones, 2006).

Konsep dasar dari teori Beck adalah kognisi melibatkan pengalaman dan pengontrolan tentang bagaimana seseorang mengidentifikasi informasi menjadi pantas untuk diadaptasi yang akan diperkuat dengan pengalaman lebih lanjut. Ketika seseorang yang memproses informasi, seperti mengambil kesimpulan sewenang-wenang membuat informasi menjadi distorsi (Nelson-Jones, 2006). Pemikiran-pemikiran negatif yang subjek miliki, telah menjadi keyakinan bagi subjek bahwa informasi yang salah menjadi informasi yang benar sehingga pemikiran negatif menjadi lebih kuat karena adanya pengalaman.

Pemikiran negatif terkubur sebagai keyakinan dan diperkuat oleh skema yang membuat subjek meyakini dan berasumsi lebih dalam dari proses berpikir untuk mengadaptasi sebuah informasi (Nelson-Jones, 2006). Ketika masalah terjadi, pikiran negatif muncul saat individu cenderung menyalahkan diri sehingga akhirnya merasa depresi (Power \& Dalgeish, 2008). Depresi bukan hanya berasal dari gangguan emosi namun juga bagian dari mekanisme interaksi yang meliputi biologis, psikologis, dan faktor sosial (Power \& Dalgeish, 2008).

\section{Formulasi Kasus}

Ada beberapa komponen penting dalam formulasi kasus menurut pendekatan kognitif diantaranya dasar teoritis, variabel relevan dan tidak relevan, peran penelitian dan pengalaman klinis, formulasi, sejarah, faktor saat ini, rencana pengobatan, proses pengobatan, faktor lain, dan simpulan yang telah dibahas dibawah ini Sturmey (2009). Dalam penelitian ini memperlihatkan adanya permasalahan pemikiran negatif dari subjek yang memiliki diagnosa depresi dengan gejala psikotik. Peneliti akan memberikan intervensi berupa terapi kognitig dengan teknik reframing dikarenakan subjek memiliki keinginan yang tinggi untuk sembuh. Intervensi dilakukan dengan empat tahap, 7 sesi dan 2 jam tiap sesinya (lihat Figure 1).

\section{Intervensi}

\section{Jenis Intervensi}

Target dalam intervensi ini adalah membantu Nana untuk menurunkan gejala depresi. Terapi yang digunakan adalah terapi kognitif dengan teknik reframing untuk mengubah sudut pandang terhadap sebuah situasi yang menjadi distorsi

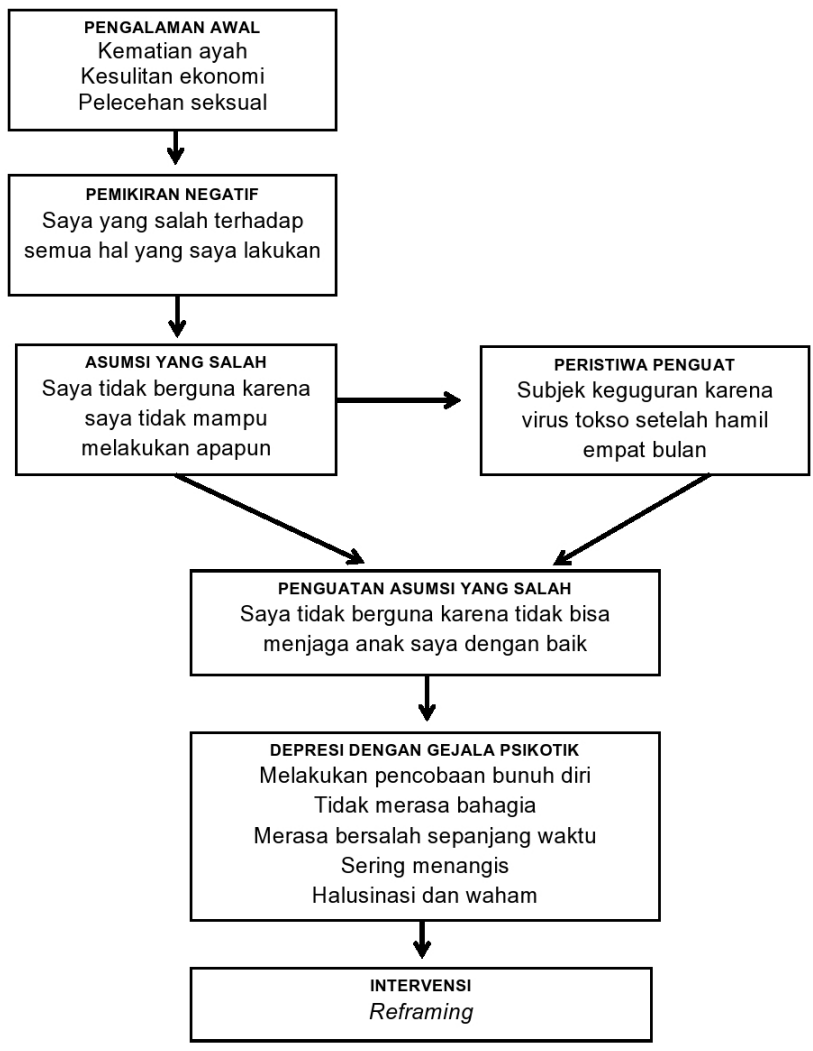

Gambar 1. Dinamika masalah yang dialami klien.

dalam hidup Nana sehingga Nana lebih terbuka terhadap solusi. Beck menyatakan bahwa depresi bukan hanya sebuah keadaan mood melainkan juga keadaan kognitif. Depresi memiliki tiga pandangan negatif yaitu terhadap diri sendiri, pengalaman masa lalu, dan masa depan (Nelson-Jones, 2006).

Reframing adalah salah satu teknik terapi yang didasari oleh pendekatan kognitif. Dalam teknik reframing, subjek diminta untuk me-reframe kembali masalahnya dengan lebih positif dan produktif sesuai dengan kebutuhan subjek (Erford, 2017). Reframing bekerja berdasarkan pemikiran bahwa masalah perilaku dan emosi bukan disebabkan oleh kejadian namun oleh bagaimana kejadian tersebut dilihat (Erford, 2017). Reframing dapat diaplikasikan melalui tiga langkah utama, mendengarkan tanpa menghakimi, memahami masalah dan membangun jembatan dari sudut pandang baru untuk melihat masalah, dan menegakkan jembatan hingga adanya perubahan dari perspektif (Erford, 2017).

Pemberian reframing sebagai salah satu teknik dari terapi kognitif terhadap Nana untuk menurunkan pemikiran negatif serta mengubah bagaimana Nana memandang masalah sehingga Nana mampu mengembangkan cara pandang baru terhadap masalah yang dimilikinya. Reframing adalah salah satu teknik terapi yang didasari oleh pendekatan kognitif. Dalam teknik reframing, Nana diminta untuk me-reframe kembali masalahnya dengan lebih positif dan produktif sesuai dengan kebutuhan Nana (Erford, 2017). Reframing memberikan kesempatan kepada individu untuk pembingkaian ulang dan perubahan perspektif dengan mengubah sudut pandang sehingga menciptakan makna yang berbeda untuk memahami dunia Schütte (2015). 
Reframing disebut juga pembingkaian ulang dengan cara mengubah sudut pandang konseptual yang erat kaitannya dengan situasi yang dialami . Pembingkaian ulang membantu menempatkan situasi dalam bingkai yang berbeda sesuai dengan fakta konkrit juga meninjau seluruh maknanya (Robson Jr \& Troutman-Jordan, 2014).

Reframing menjadi salah satu teknik yang digunakan dalam menangani depresi. Karena depresi berawal dari faktor eksternal seperti masalah sosial, keluarga, dan hubungan maka reframing membantu membingkai ulang masalahmasalah tersebut menjadi makna yang baru sehingga membantu individu untuk dapat menangani pandangan buruk terhadap masalah yang sedang dihadapi (Leung et al., 2012). Intervensi dilakukan selama 14 jam dengan 2 jam tiap sesinya. Dalam intervensi, keluarga seperti anak dan suami dilibatkan dalam beberapa tahap seperti saat komitmen untuk berubah.

\section{Tahapan Terapi}

Tahap 1: Membangun Hubungan dengan Subjek \& Komitmen untuk berubah (1 Sesi). Target dalam sesi ini, Terapis dan subjek membangun hubungan yang baik agar terciptanya kenyamanan selama proses intervensi berlangsung, dan targetnya dalam sesi ini subjek mampu menyadari bahwa pemikiran-pemikiran yang subjek pertahankan saat ini adalah salah, dan subjek diharapkan sadar bahwa subjek mampu mengubah cara pandangnya terhadap sebuah situasi yang menekan sehingga subjek mendapatkan sudut pandang baru dan meraih solusi dari setiap masalahnya.

Tahap 2: Mengidentifikasi pemikiran (1 Sesi). Sesi ini adalah sesi dimana terapis mendengarkan semua apa yang subjek katakan, lalu terapis mengambil pemikiran-pemikiran subjek yang dapat direframe kembali untuk mendapatkan sudut pandang yang baru bersama solusi dari masalah tersebut.

Tahap 3: Implementasi program (Reframe) (3 Sesi). Subjek diminta untuk me-reframe apa saja pemikiranpemikirannya ke arah yang lebih positif sehingga menciptakan solusi baru dengan sudut pandang yang berbeda. Ketika Subjek tidak mampu melakukannya, terapis dapat mencontohkan salah satu pemikiran lalu subjek akan mulai mencoba lagi untuk me-reframe pemikiran miliknya.

Reframing dan rellabeling. Setelah subjek mencoba mengubah pemikiran negatifnya menjadi sudut pandang yang baru dan subjek mencoba untuk mengganti kata sifat negatif menjadi kata sifat yang lebih positif. Terapis akan memberikan beberapa kata sifat negatif yang subjek keluarkan saat identifikasi di sesi 2 dan Subjek diminta untuk mengubah kata tersebut ke kata yang lebih positif. Sesi ini memberikan subjek kebiasaan baru untuk mengubah katakata negatif milik subjek.

Reframing dan homework. Subjek diminta untuk mengubah sudut pandangnya terhadap pemikiran negatif yang subjek miliki. Subjek juga diberikan tugas rumah terkait pemikiran negatif yang subjek ubah menjadi hal yang lebih positif. Sesi ini sebagai proses akhir dari latihan subjek dan subjek diminta mengubah pemikiran negatif tanpa bantuan terapis dengan cara mengerjakan tugas diluar dari sesi terapi.

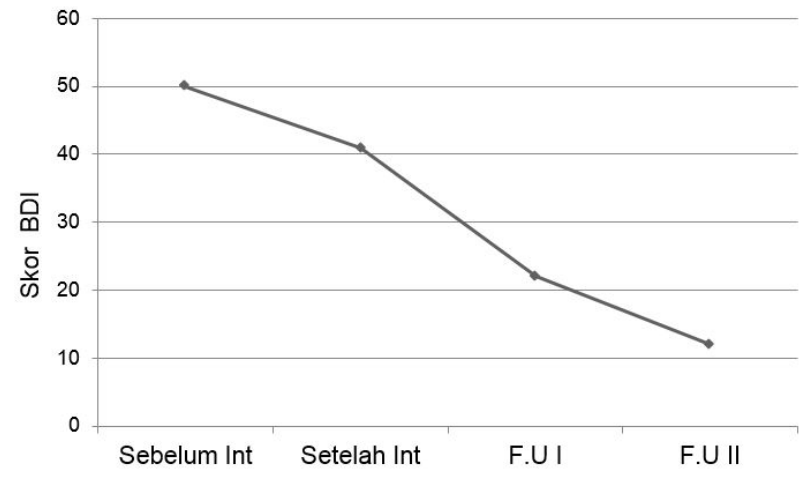

Gambar 2. Tingkat penurunan gejala depresi yang diukur melalui Beck Depression Inventory.

Tahap 4: Mempertahankan perilaku dan pencegahan (2 Sesi).

Mempertahankan perilaku dan pencegahan $I$. Bagaimana subjek mempertahankan reframing dan mencegah pemikiran-pemikiran negatif kembali muncul. Subjek dapat melakukan relaksasi dan berusaha me-reframe pemikiran-pemikiran yang muncul. Dalam sesi ini, terapis dan subjek mengevaluasi tugas rumah yang telah subjek kerjakan selama tiga hari.

Mempertahankan perilaku dan pencegahan II. Bagaimana subjek mempertahankan perilaku reframing dan mencegah pemikiran-pemikiran negatif kembali muncul melalui edukasi thought stopping dan berusaha me-reframe pemikiran-pemikiran yang muncul.

\section{Hasil dan Pembahasan}

\section{Perubahan Subjek}

Terapi yang dilakukan sebanyak tujuh sesi mendapatkan hasil yang baik. Selama proses terapi, subjek mampu bekerja sama dengan baik untuk mencapai target. Pada tahap sebelum diadakannya terapi subjek mempercayai bahwa semua ucapan negatif yang ia terima dari orang lain adalah benar dan setiap ucapan positif yang ia terima adalah kebohongan. Namun Subjek berusaha mengubah dirinya dengan bantuan terapis sehingga mendapatkan hasil yang memuaskan. Figur 2 menunjukkan arah perubahan kondisi klien.

Sebelum diberikan intervensi, Nana memiliki skor BDI 50, setelah diberikan intervensi skor BDI Nana turun menjadi 41. Dalam follow up I, memperlihatkan bahwa Nana berada di kategori depresi sedang dengan skor 22, sedangkan dalam follow up II Nana berada pada kategori depresi ringan dengan skor 12. Memperlihatkan adanya penurunan yang signifikan terhadap depresi Nana setelah dilakukannya intervensi.

\section{Perubahan dalam Proses Terapi}

Melalui observasi, terdapat perbedaan pada pola pikir Nana dari sebelum dan setelah terapi. Pada sesi pertama selama proses terapi, Nana beberapa kali terlihat ingin menangis namun Nana menahannya. Nana menyadari bahwa pemikiran negatif yang Nana pertahankan selama ini adalah hal yang salah. Nana juga memahami bahwa ia harus 
mengubah caranya melihat masalah dari sudut pandang yang berbeda. Nana yakin bahwa ia mampu berubah dan keyakinannya berada pada angka 50\%. Dari hasil sesi ini, dapat disimpulkan bahwa Nana berkomitmen dan yakin bahwa Nana mampu berubah.

Pada sesi kedua, Nana awalnya merasa kesulitan untuk mencari pemikiran negatif dari dirinya walaupun Nana telah memahami definisi dari pemikiran negatif. Nana diminta untuk bercerita dan terapis membantu Nana untuk mengidentifikasi pemikiran negatif dari cerita Nana. Akhir dari sesi, Nana akhirnya mampu mengidentifikasi pemikiran negatif tanpa bantuan terapis.

Pada sesi ketiga, Nana mencoba me-reframe pemikiran negatif Nana ke arah yang lebih positif. Pada pemikiran negatif pertama "Saya jahat buat anak-anak". Nana kesulitan untuk melakukan rellabeling pernyataan tersebut, namun saat dibantu terapis Nana mampu mengubahnya dengan "Saya tidak jahat, itu salah satu bentuk rasa sayang". Nana mampu mencoba mengubah cara pandang Nana terhadap pemikiran negatif sehingga ada solusi baru dari masalah tersebut.

Pada sesi keempat, Nana mulai mencoba me-rellabeling pernyataan "Anak-anak tidak butuh saya" tanpa bantuan terapis. Nana terlihat cukup kesulitan karena berfokus pada rasa sakitnya ketika melihat anak-anak lebih memilih ayah daripada bundanya. Namun Nana akhirnya mampu mengubah cara pandang tersebut dengan "Ayah dan bunda punya porsi masing-masing untuk anak, jadi kalimat anak tidak butuh saya itu salah". Nana juga meyakini pemikiran yang lebih positif itu sebagai hal yang benar.

Pada sesi kelima, Nana mengucapkan kalimat "Saya useless daripada orang lain" Nana mampu mengubah sudut pandang dari pernyataan tersebut menjadi, "Wanita karir belum tentu punya waktu untuk anaknya, saya punya lebih banyak waktu untuk anak-anak karena ibu rumah tangga". Nana terlihat cukup yakin dengan pemikiran yang lebih positif. Nana diberikan tugas rumah terkait pemikiranpemikiran positif yang harus ia terapkan dalam keseharian Nana untuk diri dan orang lain. Nana diberikan tugas rumah berupa menuliskan pemikiran-pemikiran positif yang Nana miliki terhadap orang lain dan dirinya sendiri.

Pada sesi keenam, Nana mengaku bahwa ia awalnya merasa kesulitan untuk mengubah pemikiran negatifnya. Namun setelah pemikiran negatif yang ketiga, Nana merasa lebih mudah untuk menemukan sudut pandang lain dari masalahnya sehingga Nana mampu menemukan pemikiran yang lebih positif. Pada sesi ini, dilakukan juga diminta mengulangi atau me-reframe pernyataan-pertanyaan yang disebutkan oleh terapis. Dalam hasil di sesi ini, Nana mampu me-reframe pernyataan-pernyataan tersebut.

Pada sesi ketujuh, terapis memberikan pemahaman terkait thought stopping agar ketika Nana berpikiran negatif secara otomatis, Nana mencoba berhenti dengan menggunakan kata 'tidak' sama seperti yang Nana lakukan ketika Nana mendengar sesuatu dari telinganya. Pencegahan ini, berhasil diterapkan oleh Nana dikarenakan Nana merasa bahwa mengabaikan halusinasi sudah sering ia lakukan, dan Nana telah mampu mengubah pemikiran negatifnya menjadi pemikiran yang lebih positif.

Follow up, dilakukan 2 kali setelah intervensi, pada follow up yang pertama dilakukan setelah dua minggu dari sesi terminasi. Guna untuk melihat apakah Nana mampu mengaplikasikan teknik reframing yang telah diberikan tanpa bantuan dari terapis. Selama proses follow up, Nana menyatakan bahwa hidup yang seperti saat ini lebih baik dari yang sebelumnya. Nana masih mencoba untuk terus mengubah pemikiran negatifnya dan melihat perspektif masalah dari berbagai sisi. Nana menyatakan bahwa ia akan berpikir dua kali sebelum bertindak. Namun Nana merasa bahwa dirinya bisikan ditelinganya membuatnya sangat terganggu. Dalam post-test BDI yang diberikan memperlihatkan skor 22 dengan kategori depresi sedang.

Pada follow up kedua pada dua bulan dari sesi terminasi untuk melihat apakah reframing dapat diaplikasikan dalam jangka waktu yang lama pada penderita depresi dengan gejala psikotik. Pada follow up kedua, terapis memberikan kembali BDI untuk mengukur bagaimana tingkat depresi Nana selama dua bulan terakhir. Hasil dari BDI Nana mendapatkan skor 12 dengan kategori gangguan suasana hati ringan.

Dalam hasil akhir memperlihatkan beberapa perubahan terhadap subjek dengan hasil follow up yang didapat setelah dua bulan yang memperlihatkan kategori depresi ringan. Dalam proses berjalannya kasus, ada beberapa tahapan karateristik seperti tahap penolakan, tahap ketidakyakinan, tahap kepercayaan, dan tahap belajar. Pada tahap penolakan, Nana sempat menolak untuk sembuh karena merasa nyaman dengan halusinasi yang ia miliki terkait anak pertamanya. Terapis memberikan pemahaman terkait keuntungan jika ia sembuh dan kerugian jika ia tetap berada dalam pemikiran negatifnya. Pada tahap ketidakyakinan, Nana mulai berpikir bahwa ia tidak bisa sembuh. Saat itu ada masalah terkait obat yang diberikan psikiaternya sehingga ketidakyakinannya untuk menjalani intervensi terkait halusinasi dan pemikiran negatif sangat tinggi. Namun tahap ketidakyakinan reda ketika terapis meyakinkan bahwa pengobatannya melalui psikiater dapat berjalan. Pada tahap selanjutnya adalah tahap kepercayaan ketika Nana mulai mampu menyadari pemikiran negatif dan mulai menjalani proses intervensi kognitif. Tahap terakhir adalah belajar dimana Nana mulai mempelajari bagaimana cara membingkai ulang atau reframing melalui pendekatan kognitif.

Seseorang dengan kemampuan berpikir positif yang rendah akan memberikan dampak terhadap kehidupannya, berpikiran negatif akan menimbulkan perasaan negatif, bahkan perilaku yang negatif (Bayu, 2016). Banyak efektifitas yang telah terbukti melalui teknik reframing. Reframing adalah bagian dari terapi kognitif yang dikembangkan oleh Beck untuk penderita depresi (Erford, 2017). Dalam penelitian sebelumnya menyatakan bahwa teknik reframing efektif digunakan untuk meningkatkan pemikiran positif (Lambert et al., 2012). Reframing dapat menjadi alternatif jika perubahan dari sudut pandang dapat benar-benar dipercaya (Erford, 2017).

Pemikiran negatif Nana terkait semua masalah yang Nana hadapi membuat Nana kesulitan dalam berpikir positif sehingga Nana cenderung banyak merasa bersalah dan sulit untuk mengkomunikasi rasa bersalahnya. Reframing membatu Nana untuk memaknai sesuatu secara lebih positif (Zulfadli, 2011, Juni 16). Terapi kognitif membutuhkan intelegensi rata-rata dalam pemberian intervensi, namun Nana yang memiliki tingkat intelegensi dibawah rata-rata mampu menerima treatment dan insight sesuai dengan 
prosedurnya. Hal yang harus dilihat dari kemampuan Nana dalam menerima terapi adalah berdasarkan pendidikan yang Nana miliki (Astuti et al., 2010), dapat juga dilihat melalui observasi dan wawancara dengan terapis. Nana mengalami penurunan fungsi kognitif namun dalam latar belakang Nana berpendidikan sarjana. Selama proses pengerjaan tes intelegensi Nana juga terganggu oleh saraf wajah yang tegang dan membuat Nana kesulitan untuk berkonsentrasi.

Nana menyatakan bahwa ia merasakan perbedaan ketika Nana berpikir negatif dan mengubahnya menjadi pikiran yang lebih positif, karena pada dasarnya reframing bekerja berdasarkan pemikiran bahwa masalah perilaku dan emosi bukan disebabkan oleh kejadian namun oleh bagaimana kejadian tersebut dilihat (Erford, 2017). Pembingkaian positif terhadap masalah saling berhubungan dengan penurunan depresi (Lambert et al., 2012). melalui skor BDI setelah terminasi dilakukan mendapatkan hasil bahwa skor Nana berada pada kategori depresi sedang dengan skor 22. Meski begitu Nana merasa membutuhkan lebih banyak waktu untuk menerapkan agar Nana benar-benar mampu mengontrol pemikiran-pemikiran yang tidak perlu dan terus melihat masalah dari berbagai sudut pandang. Pada post-test kedua setelah dua bulan dari terminasi memperlihatkan adanya penurunan gejala depresi Nana pada post-test pertama dengan skor BDI 12.

Efektifitas dari reframing dapat terlihat dalam jangka panjang meski penelitian sebelumnya menyatakan bahwa efek dari cognitive-behavior therapy pada depresi tidak efektif untuk jangka panjang (Osborn et al., 2006). Bagi penderita depresi, lebih dibutuhkan terapi kognitif yang memiliki efektifitas lebih baik daripada hanya menggunakan terapi kognitif (Rupke et al., 2006). Melalui kasus ini memperlihatkan tidak adanya penguatan-penguatan perilaku dan lebih berfokus pada terapi kognitif. Meski begitu, perilaku perubahan subjek dicatat melalui observasi yang dilakukan sebelum intervensi dilaksanakan.

Kelebihan dari intervensi ini, Nana mampu memahami setiap tahapan dan mampu menerapkan sesi persesi dengan baik, Nana bekerja sama penuh terkait dengan intervensi sehingga hasil sesuai dengan prognosis meskipun Nana memiliki intelegensi dengan kategori borderline. Kekurangannya berada pada metode asesmen dimana terapis tidak memberikan tes tambahan terkait intelegensi dikarenakan tes intelegensi yang dijalankan Nana sedikit mengalami kesulitan dikarenakan penyakit saraf Nana kambuh. Tes intelegensi tidak diberikan kembali dikarenakan waktu yang singkat dan peminjaman tes yang tidak memungkinkan pada situasi tersebut. Namun terapis tetap melihat bagaimana Nana merespon dengan baik saat wawancara dan pengamatan berlangsung.

\section{Penutup}

\section{Simpulan}

Berdasarkan hasil asesmen ditemukan masalah yaitu pemikiran negatif seperti merasa tidak berguna dan menyalahkan dirinya sehingga menimbulkan depresi dengan gejala psikotik. Hasil dari terapi memperlihatkan bahwa terapi kognitif efektif untuk membantu untuk melihat masalah dari berbagai pandangan yang lain dan membantu pikiran negatif menjadi pikiran positif.

\section{Rekomendasi}

Berdasarkan hasil penelitian yang menyatakan bahwa reframing dapat menurunkan pemikiran negatif pada wanita depresi dengan gejala psikotik, diharapkan kepada individu untuk mampu memberikan pandangan luas terhadap masalah yang dihadapi, mempersepsikan diri dan orang lain secara lebih positif, dan memiliki kesadaran diri yang tinggi terhadap pentingnya kesehatan mental. Bagi peneliti selanjutnya untuk dapat mengembangkan penelitian dimasa depan dengan lebih baik disarankan untuk memberikan originalitas terhadap pemilihan subjek maupun intervensi yang dilengkapi instrumen dengan analisis yang lebih mendalam.

\section{Referensi}

Ahmed, G., Negash, A., Kerebih, H., Alemu, D., \& Tesfaye, Y. (2020). Prevalence and associated factors of depression among Jimma University students. A cross-sectional study. International journal of mental health systems, 14(1), pp 1-10.

Alnahdi, G. H. (2015). Single-subject designs in special education: advantages and limitations. Journal of Research in Special Educational Needs, 15(4), 257-265.

Al Omari, O., Al Sabei, S., Al Rawajfah, O., Abu Sharour, L., Aljohani, K., Alomari, K., \& Anwar, S. (2020). Prevalence and predictors of depression, anxiety, and stress among youth at the time of covid-19: an online cross-sectional multicountry study. Depression research and treatment, 2020:8887727, pp 1-9. doi: $10.1155 / 2020$

American Psychiatric Association. (2013). Diagnostic and statistical manual of mental disorders fifth edition. Washington DC: CBS Publisher \& Distributors Pvt Ltd.

Amrai, K., Zalani, H. A., Arfai, F. S., \& Sharifian, M. S. (2011). The relationship between the religious orientation and anxiety and depression of students. Procedia-Social and Behavioral Sciences, 15, pp 613-616.

Astuti, W, M., Sumarwati, M., \& Seyiono, T. (2010). Pengaruh terapi kognitif restrukturisasi terhadap penurunan skor depresi pada pasien gangguan jiwa. Jurnal keperawatan Soedirman 5(3) pp 164-173.

Bayu V., S., M. (2016). Penerapan strategi reframing untuk meningkatkan kemampuan berpikir positif siswa kelas x APK2 SMKN 1 Surabaya. Jurnal Bk Unesa, 6(1) pp 1-7.

Beck, A. T. (1967). Depression: Clinical, experimentaland theoretical aspects. New York: Harper \& Row.

Beck, A. T. (2008). The evolution of the cognitive model of depression and its neurobiological correlates. American Journal of Psychiatry, 165(8), pp 969-977.

Beck, A. T., Rush, A. J., Shaw, B. F., \& Emery, G.(1979). Cognitive therapy of depression. New York:Guilford Press.

Berg, M., Andersson, G., \& Rozental, A. (2020). Knowledge about treatment, anxiety, and depression in association with internetbase cognitive behavioral therapy for adolescent: Development and initial evaluation of a new test. SAGE Open, 10(1) pp 1-11. doi.org/10.1177/2158244019899095

Chin, W. Y., Chan, K. T., Lam, C. L., Wong, S. Y., Fong, D. Y., Lo, Y. Y., ... \& Chiu, B. C. (2014). Detection and management of depression in adult primary care patients in Hong Kong: a cross-sectional survey conducted by a primary care practicebased research network. BMC family practice, 15(1), pp 1-13. 
doi:10.1186/1471-2296-15-30

Choi, E. P. H., Hui, B. P. H., \& Wan, E. Y. F. (2020). Depression and anxiety in hong kong during COVID-19. International Journal of Environmental Research and Public Health, 17(10) pp 1-11, doi:10.3390/ijerph17103740.

Choon, M. W., Abu Talib, M., Yaacob, S. N., Awang, H., Tan, J. P., Hassan, S., \& Ismail, Z. (2014). Negative automatic thoughts as a mediator of the relationship between depression and suicidal behaviour in an at-risk sample of Malaysian adolescents. Child and Adolescent Mental Health, 20(2), pp 89-93. doi:10.1111/camh.12075.

Creswell, J. W. (2015). Penelitian kualitatif \& desain riset. Yogyakarta: Pustaka Pelajar.

Cuijpers, P., Stringaris, A., \& Wolpert, M. (2020). Treatment outcomes for depression: challenges and opportunities. The Lancet Psychiatry.

Erford, B., T. (2017). 40 Teknik yang harus diketahui setiap konselor edisi kedua. Yogyakarta: Pustaka Belajar.

Fekadu, N., Shibeshi, W., \& Engidawork, E. (2017). Major depressive disorder: pathophysiology and clinical management. Journal of Depression and Anxiety, 6(1), pp 1-7. DOI: 10.4172/2167-1044.1000255

Figueroa, C. A., Ruhé, H. G., Koeter, M. W., Spinhoven, P., Van der Does,W., Bockting, C. L., \& Schene, A. H. (2015). Cognitive reactivity ver-sus dysfunctional cognitions and the prediction of relapse in recur-rent major depressive disorder Journal of Clinical Psychiatry, 76(10), pp 1306 - 1312 10.4088/JCP.14m09268

Ghorbani, N., Krauss, S. W., Watson, P. J., \& LeBreton, D. (2008). Relationship of perceived stress with depression: Complete mediation by perceived control and anxiety in Iran and the United States. International Journal of Psychology, 43(6), pp 958-968. doi:10.1080/00207590701295264

Hanke, J. E. \& Wichers, D. W. (2005). Business forecasting eight edition. New jersey: Pearson Prentice hall.

Heriyanto. (2018). Thematic analysis sebagai metode menganalisa data untuk penelitian kualitatif. ANUVA Vol 2(3): pp 317-324,

Iddon, J, L., \& Grant, L. (2013). Behavioural and cognitive treatment interventions in depression: An analusis of the evidence base. Journal of Depression Vol 2(2) pp 11-15. Doi: 10.4236/ojd.2013.22003

Lambert, N, M., Fincham, F, D., \& Stillman, T, F. (2012). Gratitude and depressive symptoms: the role of positive reframing and positive emotion. Journal of Cognition and Emotion. 26(4), pp 615-633.

Leadholm, A. K. K., Rothschild, A. J., Nolen, W. A., Bech, P., Munk-Jørgensen, P., \& Østergaard, S. D. (2013). The treatment of psychotic depression: is there consensus among guidelines and psychiatrists?. Journal of affective disorders, 145(2), 214220. https://doi.org/10.1016/j.jad.2012.07.036

Leung, P., Cheung, M., \& Tsui, V. (2012). Asian Indians and depressive symptoms: Reframing mental health help-seeking behavior. International Social Work, 55(1), 53-70.

Mohammadkhani, P., Bagheri, M., Dobson, K. S., Eskandari, E., Dejman, M., Bass, J., \& Abdi, F. (2018). Negative thoughts in depression: a study in iran. International Journal of Psychology 55(1) pp 83-89.. doi:10.1002/ijop.12541

Nasir, R., Zamani, Z. A., Khairudin, R., \& Latipun. (2010). Effects of Family Functioning, Self-esteem, and Cognitive Distortion on Depression among Malay and Indonesian
Juvenile Delinquents. Procedia - Social and Behavioral Sciences, 7 (C), 613-620. doi:10.1016/j.sbspro.2010.10.083

National Institute for Health \& Clinical Excellence. (2010). Depression the treatment and management of depression in adults (updated edition). London: The British Psychological Society

Nelson-Jones, R. (2006). Teori dan praktik konseling dan terapi (4th Ed). Yogyakarta: Pustaka Belajar.

Osborn, R. L., Demoncada, A. C., \& Feuerstein, M. (2006). Psychosocial Interventions for Depression, Anxiety, and Quality of Life in Cancer Survivors: Meta-Analyses. The International Journal of Psychiatry in Medicine, 36(1), pp 13-34. doi:10.2190/eufn-rv1k-y3tr-fk01.

Ozdemir, O., Özdemir, P. G., Milanlıglu, A., Tapanci, Z., \& Timucin, D. K. (2015). Is major depressive disorder with psychotic features more likely in elderly than adulthood?. Psychiatry and Behavioral Sciences, 5(1), 3-7. doi: 10.5455/jmood.20140908060721

Permuy, B., Merino, H., \& Fernandez-Rey, J. (2010). Adult attachment styles and cognitive vulnerability to depression in a sample of undergraduate students: The mediational roles of sociotropy and autonomy. International Journal of Psychology, 45(1), pp 21-27.

Panayiotou, G., \& Papageorgiou, M. (2007). Depressed mood: The role of negative thoughts, self-consciousness, and sex role stereotypes. International Journal of Psychology, 42(5), pp 289-296. doi:10.1080/00207590701318389.

Philippi, C. L., Cornejo, M. D., Frost, C. P., Walsh, E. C., Hoks, R. M., Birn, R., \& Abercrombie, H. C. (2018). Neural and behavioral correlates of negative self-focused thought associated with depression. Human Brain Mapping, 39(5), pp 2246-2257. doi:10.1002/hbm.24003

Pietromonaco, P. R., \& Markus, H. (1985). The nature of negative thoughts in depression. Journal of Personality and Social Psychology, 48(3), pp 799-807. doi:10.1037/00223514.48.3.799.

Power, M \& Dalgeish, T. (2008). Cognition And Emotion From Order To Disorder 2thed. Canada: Psychology Press.

Prihatsanti, U., Suryanto., \& Hendriani, W. (2018). Menggunakan studi kasus sebagai metode ilmiah dalam psikologi. Buletin Psikologi. DOI: 10.22146/buletinpsikologi.38895.

Rnic, K., Dozois, D. J., \& Martin, R. A. (2016). Cognitive distortions, humor styles, and depression. Europe's journal of psychology, 12(3), pp 348-362,

Robson Jr, J. P., \& Troutman-Jordan, M. (2014). A concept analysis of cognitive reframing. Journal of Theory Construction \& Testing, 18(2) pp 55-59.

Rothschild, A. J. (2013). Challenges in the treatment of major depressive disorder with psychotic features. Schizophrenia bulletin, 39(4), 787-796. https://doi.org/10.1093/schbul/sbt046

Rupke, S. J., Blecke, D., \& Renfrow, M. (2006). Cognitive therapy for depression. American Family Physician, 73(1), pp 83-86.

Sasaki, J., Sakamoto, S., Moriwaki, A., Inoue, K., \& Ugajin, K. (2013). The recognized benefits of negative thinking/affect in depression and anxiety: developing a scale. Japanese Psychological Research, 55(3), pp 203-215. doi:10.1111/jpr.12008.

Schütte, B. (2015). Remarkable Reframing. Journal of Mediation \& Applied Conflict Analysis, 2(2), 1-11. https://doi.org/10.33232/jmaca.2.2.6257 
Skapinakis, P., Bellos, S., Oikonomou, A., Dimitriadis, G., Gkikas, P., Perdikari, E., \& Mavreas, V. (2020). Depression and its relationship with coping strategies and illness perceptions during the COVID-19 lockdown in Greece: a cross-sectional survey of the population. Depression research and treatment, 2020. Article ID 3158954. Pp 1-11. https://doi.org/10.1155/2020/3158954

Sorayah. (2015). Uji validitas konstruk beck depression inventory-II (BDI-II). JP3I Vol 4(1). Pp 1-13. Doi: 10.15408/jp3i.v4i1.9259

Sturmey, P. (Ed.). (2009). Clinical case formulation: Varieties of approaches. John Wiley \& Sons.

Teasdale, J. D. (1983). Negative thinking in depression: Cause, effect, or reciprocal relationship? Advances in Behaviour Research and Therapy, 5(1), pp 3-25. doi:10.1016/01466402(83)90013-9
Tusa, B. S., Alemayehu, M., Weldesenbet, A. B., Kebede, S. A., \& Dagne, G. A. (2020). Prevalence of depression and associated factors among diabetes patients in east shewa, ethiopia: bayesian approach. Depression Research and Treatment, V 2020(11) pp 1-11. https://doi.org/10.1155/2020/4071575

Tyrka, A. R., Price, L. H., Mello, M. F., Mello, A. F., \& Carpenter, L. L. (2006). Psychotic major depression. Drug safety, 29(6), pp 491-508. doi: 10.2165/00002018-200629060-00003.

Üstün, TB., Kostanjsek, N., Chatterji, S., \& Rehm, J. (2010). Measuring health and disability: Manual for WHO disability assessment schedule (WHODAS 2.0). World Health Organization.

Vass, V, A. (1992). Standardization of Raven's standard progressive matrices for secondary scholl african pupils in the grahamstown region. Rhodes University.

Zulfadli. (2011, Juni 16) Reframing, Hanya Perlu Bertindak Wajar. Artikel Kompasiana. Diakses pada 20 Agustus 2020. https://www.kompasiana.com/cuba/. 